\title{
ESTABLISHMENT OF THE INVASIVE PEST OF BAMBOO DINODERUS JAPONICUS LESNÉ, 1895 (COLEOPTERA BOSTRICHIDAE) IN THE CAUCASUS AND NOTES ON OTHER BEETLE SPECIES CURRENTLY ESTABLISHED IN THIS REGION
}

(*) A.N. Severtsov Institute of Ecology and Evolution, Leninskij pr. 33, Moscow 119071, Russia; e-mail: bienkowski@yandex.ru, marinaorlben@yandex.ru

Bieńkowski A.O., Orlova-Bienkowskaja M.J. - Establishment of the invasive pest of bamboo Dinoderus japonicus Lesné,
1895 (Coleoptera Bostrichidae) in the Caucasus and notes on other beetle species currently established in this region.

Dinoderus japonicus Lesné, 1895, a beetle native to East Asia, is firstly recorded in Russia and the Caucasus. In May 2016 three specimens of this serious pest of bamboo were collected in the thicket of Phyllostachys sp. in Sochi (near the Black Sea Coast in the South of European Russia), where bamboo is widely cultivated as an ornamental plant. Probably this record represents a successful establishment, since the likelihood of catching three individuals from a current introduction, rather than from a breeding population, is vanishingly small. Dinoderus japonicus was often intercepted in Europe, but did not establish until recently. However in 2012-2013 established populations were found in France and Italy. The record of one more population - in the Caucasus - indicates that the pest potentially could be established in any region of Europe, where bamboo is cultivated. Therefore, it is recommended to survey bamboo plantations in all regions for this pest. The populations of at least 14 alien beetle species have been firstly recorded in European Russia in Sochi since 2000. Special phytosanitary measures should be taken in this region to prevent future invasions.

KeY Words: Dinoderus japonicus, pest of bamboo, Japanese Shot-Hole Borer, exotic species, the Caucasus.

\section{INTRODUCTION}

Invasions of alien beetle species to Europe cause significant economic loss and are a major threat to biodiversity loss (KENIS \& BRANCO, 2010). In the 21 st century invasions of beetles from other regions, especially from Asia, is increasing dramatically (DENUX \& ZAGATTI, 2010). Many beetle species naturalized in Europe in the last years. In particular, the Japanese Shot-Hole Borer Dinoderus (Dinoderastes) japonicus Lesné, 1895 (Coleoptera, Bostrichidae) recently established in France (BRUSTEL \& ABERLEnc, 2014) and in Italy (NARDi et al., 2015). The first record of established population of this species in the Caucasus is reported herein. It is the third record of established population in Europe and the first record of $D$. japonicus in Russia.

Two species of Dinoderus were already known from Russia: Dinoderus (Dinoderus) minutus (Fabricius, 1775) and Dinoderus (Dinoderus) bifoveolatus (Wollaston, 1858). Both are alien. Only $D$. minutus is established, while $D$. bifoveolatus was only intercepted. Until recently, $D$. japonicus was not recorded from Russia (KRIVOLUTSKAYA, 1992).

\section{MATERIALS AND METHODS}

The collecting site of D. japonicus is located in the south of European Russia in the Northwest Caucasus near the Black Sea Coast (Krasnodar Krai, Sochi, Krasnoselskaya Str., 43.575921N, 39.761427E). The climate of Sochi is humid subtropical with a warm rainy winter and a sunny summer. The average annual temperature is $+14.2{ }^{\circ} \mathrm{C}$. The average annual precipitation is $1703 \mathrm{~mm}$. The coldest months in the city are January and February with an average temperature of $+6.0^{\circ} \mathrm{C}$. The warmest month is August, its average daily temperature is $+23.6^{\circ} \mathrm{C}$.

Bamboo (Phyllostachys aurea and P. bambusoides) is widely cultivated in Sochi as an ornamental plant and often occurs outside plantations as an adventive plant. Probably bamboo became widely planted in Sochi after 1925, when the city became a resort.

Three adults of $D$. japonicus were collected in pitfall traps settled in a thicket of Phyllostachys sp. near houses. Trapping period spanned from 18 May to 23 May 2016. The species was identified referring to LESNÉ (1895), BOROWSKI \& WĘGRZYNOWICZ (2012) and WALKER (2007).

\section{DIAGNOSTIC CHARACTERS}

The genus Dinoderus Stephens, 1830 contains 26 species grouped into two subgenera: Dinoderus s. str. with 22 and Dinoderastes Lesne, 1914 with 4 species (BoROWSKI \& WęGrZYNowicz, 2013). Dinoderus japonicus (Fig. I) belongs to the subgenus Dinoderastes which differs from the subgenus Dinoderus s. str. in the following characters: first tarsomere long, at least as long as the next two together; distal tarsomere somewhat shorter than sum of others; ventral side of basal two tarsomeres with brushes of long setae (BorowsKi \& WęGRZYNOWICZ, 2012). Dinoderus japonicus can be distinguished from other species of the subgenus Dinoderastes by following characters: antennae 11-jointed; elytral setae thin, on elytral declivity apically pointed; prescutellar depressions on pronotum very shallow, hardly discernible; median two dents on anterior margin 


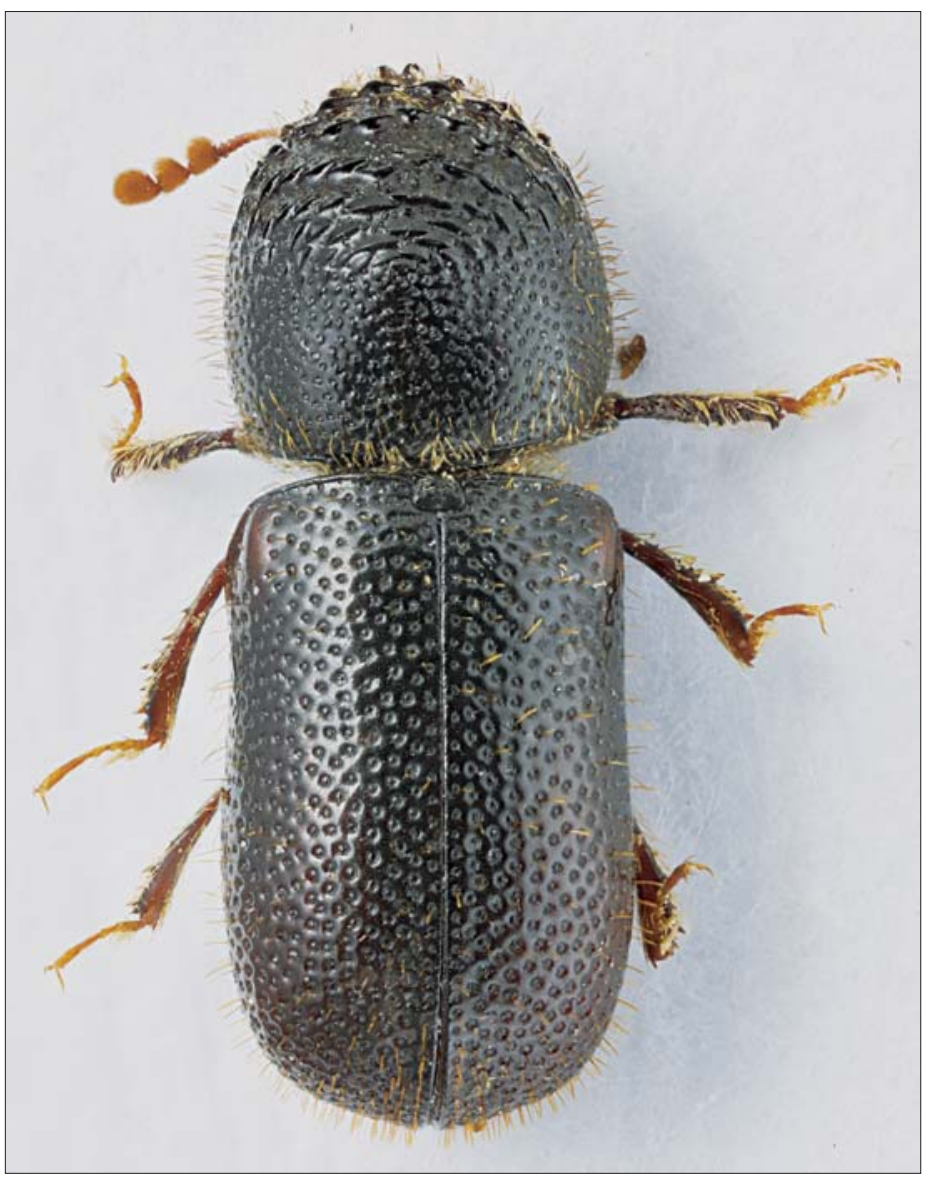

Fig. I - Dinoderus japonicus captured in Sochi, Krasnodar Krai, South of European Russia. Photo is taken by K.V. Makarov.

large, much larger than others, close to one another and produced forwards; body dark, chestnut-brown or black (BorOWSKI \& WęGRZYNOWICZ, 2012).

\section{DISCUSSION}

Species of the subgenus Dinoderus s. str. feed on Palmaceae, Anacardiaceae, Caricaceae, Bambusoideae, Dipterocarpaceae, Euphorbiaceae, Convolvulaceae, some species are polyphagous. Species of the subgenus Dinoderastes feed on Bambusoideae, Annonaceae and Dipterocarpaceae. Four species of the genus are related with bamboo: D. brevis, D. japonicus, D. ocellaris and $D$. minutus. Seven species of the genus Dinoderus are recorded in Europe: Dinoderus (Dinoderus) bifoveolatus (Wollaston, 1858), Dinoderus (Dinoderus) distinctus Lesné, 1897, Dinoderus (Dinoderus) minutus (Fabricius, 1775), Dinoderus (Dinoderus) ocellaris Stephens, 1830, Dinoderus (Dinoderus) porcellus Lesné, 1923, Dinoderus (Dinoderus) brevis Horn, 1878, and Dinoderus (Dinoderastes) japonicus (BorowsKI, 2007; BOROwSKI \& WĘGRZYNOWICZ, 2012; NARDI et al., 2015). All are alien. Dinoderus ocellaris, D. minutus and D. bifoveolatus have established in Europe as well as in other continents outside their native ranges and became almost cosmopolitan. $D$. distinctus, $D$. porcellus and $D$. brevis were only intercepted. Dinoderus bifoveolatus is a polyphagous species, which is often introduced with grains, mainly with rice. Dinoderus minutus, D. brevis and D. ocellaris feed on bamboo and are often introduced with bamboo products. Dinoderus porcellus feed on palm trees. Host plant of $D$. distinctus is unknown.
Dinoderus japonicus is frequently intercepted outside its native Asian range from imported bamboo, rattan and bamboo products (ZHI LIN et al., 2009). It was intercepted in the USA, Australia and at least in 9 European countries: Austria, Sweden, Switzerland, Great Britain, the Netherlands, Germany, Poland, France and Italy (BURAKOWSKI et al., 1986; BorowSKI, 2007; BOROWSKI \& Węgrzynowicz, 2012; Brustel \& Aberlenc, 2014; NARDI, et al., 2015). But no established populations were recorded in Europe before 2012 (BOROWSKI \& WEGRZYNOWICZ, 2012). In 2012 an established population was recorded in France: Muret (Haute-Garonne) (BRUSTEL \& ABERLENC, 2014). In 2013 a specimen of D. japonicus was collected with a trap in Italy: Veneto Region, Treviso Province, which probably indicated the existence of another established population (NARDI et al., 2015). Probably the record of D. japonicus in the Caucasus represents a successful establishment, since the likelihood of catching three individuals from a current introduction, rather than from a breeding population, is vanishingly small. Therefore, the population in the Caucasus found in 2016 is the third one in Europe. It seems that the species begins to establish in the regions of Europe, where bamboo is planted as an ornamental plant.

Why did D. japonicus begin to establish in Europe in the last years, if it did not establish before? It corresponds to the general current tendency of dramatic increase of insect invasions from Asia caused by the increase of import from this region (DENUX \& ZAGATTI, 2010). It is known that ecological resistance of native ecosystems can be overwhelmed by the increase of propagule pressure (HoLLE \& Simberloff, 2005). So it is possible that the increase the rate of introduction of $D$. japonicus from Asia has increased 
the probability of its establishment. Therefore, it is recommended to survey bamboo plantations in different regions of Europe for this pest.

Dinoderus japonicus was originally described from Japan (LESNÉ, 1895). In Asia this species occurs also in Korea and China: Hong Kong, Kiangsi, Zhejiang, Yunnan, Taiwan (Chang et al., 1979; BeloKobYLSKiJ, 2008; BorowsKi \& WęGrzynowicz, 2012; PARK et al., 2015). Dinoderus japonicus is one of the most important pests of bamboo in China (ChANG et al., 1979). It develops in sprouts, especially of the genera Phyllostachys and Pleioblastus, damages also harvested culms and finished bamboo products (WALKER, 2007; BOROWSKI \& WĘGRZYNOWICZ, 2012). Bamboo is not of the great economic importance in Europe. But this Bostrichid occasionally damages stored grain, paddy and maize (YAN et al., 2010). So it is not excluded that if the species becomes abundant, it could become a pest of stored products as D. minutus.

Currently invasions of pest insects are common in the Northwest Caucasus in the vicinity of Sochi. In 2000-2016 established populations of at least 13 other alien beetle species were firstly recorded in European Russia in this region.

Xylosandrus germanus (Blandford, 1894) (Curculionidae: Scolytinae) was first recorded in 2000 (MANDELSHTAM, 2000). It is a xylophagous beetle, pest of different deciduous and coniferous trees. This pest is native to Japan, China and Vietnam and spreading in Europe since 1951 (RABITSCH \& SCHUH, 2002). It could have been introduced to the Caucasus with imported wood.

Megabruchidius tonkineus (Pic, 1904) and M. dorsalis (Fåhraeus, 1839) (Chrysomelidae: Bruchinae) were first recorded in 2005 and 2013 respectively (KOROTYAEV, 2011; 2015). They are native to Asia and established in the south of Europe. Both species develop in seeds of Gleditsia and could have been introduced from Europe with these seeds.

Harmonia axyridis (Pallas, 1773) (Coccinelidae) is native to East Asia. It was used for biological control of aphids and other pests all over the world and become almost cosmopolitan. Established population of this species was first recorded in the Caucasus in 2012. It is suggested that it could have appeared as a result of natural dispersal from the West or originated from specimens released in this region for biocontrol of pest (BELYAKOVA \& REZNIK, 2013; UKRAINSKY \& ORLOVA-BIENKOWSKAJA, 2014).

Stelidota geminata (Say, 1825) (Nitidulidae) is native to North America and spreading in Europe at least since the 1980th. It was first recorded in the Caucasus in 2013 (TsinKEVICH \& SOLODOVNIKOV, 2014). In Europe this beetle occurs on decaying fruits on the ground and is not regarded as a pest, though in its native range it is the pest of strawberry. Probably it was introduced to the Caucasus with imported fruits.

Epitrix hirtipennis (Melsheimer, 1847) (Chrysomelidae) is a pest of tobacco and other plants of the family Solanaceae. It is native to South America and south of North America and established in South Europe in the 1980th. This pest could have been introduced to the Caucasus with seedlings, because its larvae develop on roots. It was first recorded in the Caucasus in 2013 (ORLOVA-BIENKOWSKAJA, 2014).

Rhynchophorus ferrugineus (Olivier, 1791) (Dryophthoridae) is a pest of palm trees. It is native to Oriental region and established in South Europe. Apparently it was introduced with imported seedlings of palms. It was first recorded in the Caucasus in 2014 (ZHURAVLEVA \& KARPUN, 2014).
Luperomorpha xanthodera (Fairmaire, 1888) (Chrysomelidae) is a pest of flowers. It is native to China and Korea and established in Europe. Adults feed on flowers, the larvae develop on roots (Del BenE \& CONTI, 2009; BEENEN \& ROQUES, 2010). So larvae could be introduced with seedlings. The pest was first recorded in the Caucasus in 2016 (BIEŃKOWSKI \& ORLOVA-BIENKOWSKAJA, article in press).

Medythia nigrobilineata (Motschulsky, 1861) (Chrysomelidae) is a pest of soybeans native to East Asia. It was first recorded in the Caucasus in 2016 and could have been unintentionally introduced with soybean seeds (BIEŃKOWSKI \& ORLOVA-BIENKOWSKAJA, article in press).

Lamprodila festiva (Linnaeus, 1767) (Buprestidae) is a xylophagous beetle feeding on Cupressaceae. This pest native to Mediterranean region and South Europe was first recorded in the Caucasus in 2013 (KARPUN \& VOLKOVITSH, 2016). Probably it was introduced with seedlings.

Arthrolips fasciata (Erichson, 1842) (Corylophidae) native to Tasmania, Australia and New Zealand, Silvanoprus cephalotes (Reitter, 1876) (Silvanidae) widely distributed in the Oriental and Papuan regions and also in the Palaearctic Far East, and Psammoecus trimaculatus Motschulsky, 1858 (Silvanidae) originated in the Oriental Region are associated with decaying plant substrates and could be introduced with such subatrates. These species were first recorded in the Caucasus in 2014 (Kovalev, 2016).

Probably some species, in particular Rhynchophorus ferrugineus, Luperomorpha xanthodera and Lamprodila festiva, could have been unintentionally introduced with ornamental seedlings imported from Europe when landscaping the city just before the 2014 Sochi's Olympic Games. Invasion of other species does not seem to be connected with these Olympic Games, but probably reflects the increase in import of goods, especially from China and other countries of East Asia. It is known that some regions in Europe are more prone to invasion of alien insects than others (Denux \& ZagatTi, 2010). Current data show that introduced insects could easily establish in the Black Sea shore of the Caucasus. So special quarantine measures should be taken in this region, where the risk of pest insect invasions is high.

\section{ACKNOWLEDGMENTS}

The study was supported by Russian Science Foundation, Project No 16-14-10031. We are grateful to G. Nardi (MiPAAF, Corpo Forestale dello Stato, Centro Nazionale per lo Studio e la Conservazione della Biodiversità Forestale "Bosco Fontana", Italy) and H. Brustel (Université de Toulouse, École d'Ingénieur de Purpan) for the valuable information and literature and to K.V. Makarov (Moscow State Pedagogical University, Russia) for taking the photo.

\section{REFERENCES}

Beenen R., Roques A., 2010 - Leaf and Seed Beetles (Coleoptera, Chrysomelidae). Chapter 8.3. In: Alien terrestrial arthropods of Europe; A. Roques, M. Kenis, D. Lees, C. Lopez-Vaamonde, W. Rabitsch, J.-Y. Rasplus \& D.B. Roy Ed., BioRisk. 4(1). Pensoft, Sofia - Moscow pp. 267-292.

Belokobylskij S.A., 2008 - A new genus of the tribe Doryctini (Hymenoptera, Braconidae, Doryctinae). Zoosystematica Rossica, 17(1): 123-130. 
Belyakova N.A., REZnIK S.YA., 2013 - First record of the harlequin ladybird, Harmonia axyridis (Coleoptera: Coccinellidae) in the Caucasus. - European Journal of Entomology, 110(4): 699-702.

Bieńkowski A.O., Orlova-Bienkowskaja M.J., 2017a Quick spread of the invasive rose flea beetle Luperomorpha xanthodera (Fairmaire, 1888) in Europe and its first record from Russia (Coleoptera, Chrysomelidae, Galerucinae, Alticini). - Spixiana (in press).

BieŃKOWsKi A.O., Orlova-BienKowsKaja M.J, 2017b New threat to soybean production in Europe: first record of the invasive alien pest Medythia nigrobilineata (Coleoptera, Chrysomelidae) introduced from Asia. Acta Zoologica Bulgarica (in press).

Borowski J., 2007 - Bostrychidae. In: Catalogue of Palaearctic Coleoptera, I. Löbl \& A. Smetana Ed., Vol. 4., Apollo Books, Stenstrup, pp. 320-328.

Borowski J., WęGRzYNowicz P., 2012 - The Powderpost Beetles of the World (Coleoptera: Bostrichidae). Keys for Identification of Species. Vol. I. - Kapturniki świata (Coleoptera: Bostrichidae). Klucze do oznaczania gatunków. T. I. Wydawnictwo Mantis, Olsztyn. 461 pp.

BOROWSKI J., WĘGRZYNOWICZ P., 2013 - A new species of the genus Dinoderus Stephens from Taiwan (Coleoptera: Bostrichidae, Dinoderinae). - Genus, 24 (1): 33-38.

Brustel H., Aberlenc H.-P., 2014 - Les Bostrichidae Latreille, 1802 de la faune de France: espèces autochtones, interceptées, introduites ou susceptibles de l'être (Coleoptera). - Revue de l'Association Roussillonnaise d'Entomologie, 23 (2): 65-68.

BuraKowski B., MroczKowsKi M., STEFAŃSKa J., 1986 Chrzaszcze - Coleoptera. Dermestoidea, Bostrichoidea, Cleroidea i Lymexyloidea. Katalog Fauny Polski, Vol. XXIII, Issue:11 Wydawnictwo PWN, Warszawa. 243 pp.

Chang L.-F., Chen S.-W., Chu C.-M., Ma E.-P., 1979 - A study on the biology and control of the powder-post beetle Dinoderus japonicus Lesné. - Acta Entomologica Sinica, 22 (2): 127-132 (in Chinese).

Del Bene G., Conti B. 2009 - Notes on the biology and ethology of Luperomorpha xanthodera, a flea beetle recently introduced into Europe. - Bulletin of Insectology 62 (1): 61-68.

Denux O., Zagatti P., 2010 - Coleoptera families other than Cerambycidae, Curculionidae sensu lato, Chrysomelidae sensu lato and Coccinelidae. - BioRisk, 4: 315-406.

Holle B.V., Simberloff D., 2005 - Ecological resistance to biological invasion overwhelmed by propagule pressure. Ecology, 86 (12): 3212-3218.

Karpun N.N., Volkovitsh M.G., 2016 - [Lamprodila (Palmar) festiva (L.) - A New Invasive Pest of in the Black Sea coast of the Caucasus]. In: The Kataev Memorial Readings - IX. Musolin D.L. \& Selikhovkin A.V. Ed., Saint Petersburg State Forest Technical University, Saint Petersburg. pp. 45-46. doi: 10.21266/SPBFTU.2016.9. (In Russian, English summary).

KenIS M., BRANCO M., 2010 - Impact of alien terrestrial arthropods in Europe. - BioRisk, 4 (1): 51-71.

KorotyAev B.A., 2011 - On invasion of an East Asian seed beetle, Megabruchidius tonkineus (Pic) (Coleoptera, Bruchidae), developing in Gleditsia seeds, in the Northwest Caucasus. - Entomological Review, 91 (9): 1167-1169.
KorotyaEV B.A., 2015 - Record of the second species of the East Asian seed-beetle genus Megabruchidius Borowiec (Coleoptera, Bruchidae) in the Gleditsia seeds in Krasnodar and Stavropol territories, Russia. Entomological Review, 95 (9): 1237-1239.

KovaleV A.V., 2016 - New records of adventive species of Corylophidae and Silvanidae (Coleoptera: Cucujoidea) from the Western Caucasus. - Zoosystematica Rossica, 25 (2): 273-276.

Krivolutskaya G.O., 1992 - [Family Bostrychidae Powderpost Beetles. In: Taxonomic Key to Insects of the Far East of USSR. Vol. 3. Coleopterous, or Beetles. Part 2]. Ler P.A. Ed., Nauka, St. Petersburg, pp. 60-61 (in Russian).

LESNÉ P., 1895 - Descriptions de genres nouveaux et d'espéces nouvelles de coléoptéres de la famille des Bostrychides. - Annales de la Société Entomologique de France, 64: 169-178.

Mandelshtam M.Ju., 2000 - New synonymy and new records of Palaearctic Scolytidae (Coleoptera). Zoosystematica Rossica, 9 (1): 203-204.

NARdi G., BADANo D., De CinTI B., 2015 - First record of Dinoderus (Dinoderastes) japonicus in Italy (Coleoptera: Bostrichidae). - Fragmenta entomologica, 47 (2): 147150.

OrLOVA-BIENKowsKaJA M.J., 2014 - First record of the tobacco flea beetle Epitrix hirtipennis Melsheimer [Coleoptera: Chrysomelidae: Alticinae] in Russia. EPPO Bulletin, 44 (1): 44-46.

Park S., Lee S., Hong K.-J., 2015 - Review of the family Bostrichidae (Coleoptera) of Korea. - Journal of AsiaPacific Biodiversity, 8: 298-304.

RABItsch W., Schun R. 2002 - Käfer (Coleoptera), In: Neobiota in Österreich, F. Essl \& W. Rabitsch. Umweltbundesamt, Wien, pp. 324-346.

Tsinkevich V.A., Solodovnikov I.A., 2014 - Epuraea ocularis and Stelidota geminata (Coleoptera: Nitidulidae) from Caucasus. - Zoosystematica Rossica, 23 (1): 118-121.

Ukrainsky A.S., Orlova-Bienkowskaja M. JA. 2014 Expansion of Harmonia axyridis Pallas (Coleoptera: Coccinellidae) to European Russia and adjacent regions. - Biological Invasions, 16 (5): 1003-1008.

WALKER K., 2007 - Japanese Shot-hole Borer (Dinoderus japonicus), http://www.padil.gov.au [accessed 2 February 2017]. last update 21 October 2011.

Yan X., Zhou H., Shen Z., Li W., Guo D., Song Y., Lan S., ZHANG J., 2010 - National investigations of stored grain arthropods in China. 10th International Working Conference on Stored Product Protection, pp. 212-218, DOI: $10.5073 /$ jka.2010.425.145

Zhi Lin C., Cai Yu X., DaO Jian Y., Yi J., Lang X., Yin ZHU W., 2009 - Identification on five related species of Dinoderus (Coleoptera: Bostrichidae) from imported bamboo and rattan. - Entomotaxonomia, 31 (2): 115-122 (in Chinese with English summary).

ZhURAVLEVA E.N., KARPUN N.N., 2014 - [Rhynchophorus ferrugineus - a new dangerous pest of palm trees in Sochi]. URL: http://www.vniisubtrop.ru/novosti/434novyj-opasnyj-vreditel-palm-v-sochi-krasnyj-palmovyjdolgonosik.html [accessed 27 November 2016]. last update 21 October 2011 (In Russian). 